\title{
Sedimentary facies and soft-sediment deformation structures in the late miocene-pliocene Middle Siwalik subgroup, eastern Himalaya, Darjiling District, India
}

\author{
Abhik Kundu $^{1 *}$ Abdul Matin ${ }^{2}$ Malay Mukul ${ }^{3,}$ Patrick G. Eriksson. ${ }^{4}$ \\ ${ }^{1}$ Department of Geology, Asutosh College, 92, S.P. Mukherjee Road, Kolkata 700026, India, \\ kundu.abhik@gmail.com, *Corresponding Author \\ ${ }^{2}$ Department of Geology, University of Calcutta, 35, Ballygunj Circular Road, Kolkata 700029, India,
}

amatinindia@yahoo.com

${ }^{3}$ CSIR Centre for Mathematical Modelling and Computer Simulation, Bangalore 560037, India mlym@cmmacs.ernet.in

${ }^{4}$ Dept. of Geology, University of Pretoria, Pretoria, 0002, South Africa, pat.eriksson@up.ac.za

\begin{abstract}
The Himalayan fold-and-thrust belt has propagated from its Tibetan hinterland to the southern foreland since $\sim 55 \mathrm{Ma}$. The Siwalik sediments ( 20 - $2 \mathrm{Ma})$ were deposited in the frontal Himalayan foreland basin and subsequently became part of the thrust belt since $\sim 12 \mathrm{Ma}$. Restoration of the deformed section of the Middle Siwalik sequence reveals that the sequence is $\sim 325 \mathrm{~m}$ thick. Sedimentary facies analysis of the Middle Siwalik rocks points to the deposition of the Middle Siwalik sediments in an alluvial fan setup that was affected by uplift and foreland-ward propagation of Greater and Lesser Himalayan thrusts. Soft-sediment deformation structures preserved in the Middle Siwalik sequence in the Darjiling Himalaya are interpreted to have formed by sediment liquefaction resulting from increased pore-water pressure probably due to strong seismic shaking. Soft-sediment structures such as convolute lamination, flame structures, and various kinds of deformed cross-stratification are thus recognized as palaeoseismic in origin. This is the first report of seismites from the Siwalik succession of Darjiling Himalaya which indicates just like other sectors of Siwalik foreland basin and the present-day Gangetic foreland basin that the Siwalik sediments of this sector responded to seismicity.
\end{abstract}

Keywords: soft-sediment deformation ; Seismite ; Siwalik ; Neogene ; Foreland basin ; Siwalik Sedimentary facies 


\section{INTRODUCTION}

Penecontemporaneous deformation structures generally form in unconsolidated to partly consolidated fluid-laden sand intercalated with finer sediments (Einsele et al. 1996). These structures may be: (i) syn-depositional (deformation event effective during deposition), (ii) meta-depositional (deformation after deposition but before sedimentation of younger layer) and (iii) post-depositional (deformation after deposition of the younger layer) (Nagtegaal, 1963, 1965; Allen, 1982; Owen, 1995; Mazumder et al. 2006). Though meta-depositional deformation is rarer than the other two, seismic shocks are potential triggers for meta-depositional deformation as the deformations occur after some degree of consolidation of sediments. (Mazumder et al. 2006).

Deformation of the unconsolidated sediment may be sedimentary or tectonic in origin (Owen, 1987); analogously, Leeder (1987) distinguished "allokinetic" deformation structures formed by earthquake-related stresses, from "autokinetic" or those formed solely by sedimentation processes (Røe and Hermansen, 2006). Van Loon (2009) divided these structures on the basis of genesis into (1) endoturbations (formed due to endogenic forces particularly earthquakes), (2) graviturbations (formed under the gravitational control) and (3) exoturbations (formed due to exogenic factors including sedimentation and bioturbation processes). From a single structure it is almost impossible to specify seismicity as the trigger event, but many workers have summarized some collective attributes of the soft-sediment deformation features for such an interpretation. These include the presence of soft-sediment deformation structures in discrete sediment horizons (Mazumder et al. 2006 and references therein), lateral continuity of such beds (Obermeier, 1996), their vertical repetition within a succession (Mazumder et al. 2006), 
presence of bounding undeformed beds (Sims 1973, 1975), presence of various softsediment deformation structures together (Kleverlaan, 1987; Obermeier, 1996; Pope et al. 1997; Rosetti and Góes, 2000), association with sedimentary breccias, conglomerate and massive sandstone (Mazumder et al. 2006), and deviation of palaeocurrent indicators from the normal palaeoflow pattern (Mazumder et al. 2006). According to Wheeler (2002), there will always be some degree of uncertainty about the seismic origin of soft sediment deformation structures because other causes for formation of similar structures cannot be easily ruled out. He proposed that the seismic origin of a soft sediment deformation structure or a group of structures can be tested with evidences of sudden generation of such structures, synchroneity, wide spatial distribution and favourable tectonic and depositional setting.

This paper aims to examine soft sediment deformation structures from fluvial deposits within the Neogene Middle Siwalik Subgroup of eastern Himalaya, Darjiling district, India. The source of sediments of the Siwalik basins is mainly from the rocks of the Greater Himalayan Crystalline Complex (GHC) to the north (DeCelles et al. 1998; White et al. 2001). Keeping in view the syn-tectonic deposition of Middle Siwalik sediments within the foreland basin of the Himalayan orogenic belt (Moores and Fairbridge, 1997) during the uplift of GHC in the Middle and Late Miocene (Negi, 1998; Tabata, 2004; Yin, 2006 and references therein), a strong case can be made for a predominantly seismic origin for the penecontemporaneous deformation structures in the Middle Siwalik sequence. Evidences of paleoseismicity have been reported from Siwaliks of western Himalaya (Kumar et al. 2005; Singh et al. 2007). This paper presents the first report of a suite of soft sediment deformation structures from the Middle 
Siwaliks of the eastern Himalaya of India within a set of fluvial deposits. These structures are related to a predominantly tectonic rather than a sedimentary origin. This paper thus also aims to contribute to the ongoing debate on the folding of the cross beds to recumbent folds in soft sediment deformation (e.g., Røe and Hermansen 2006, 2007; Mazumder and Altermann, 2007).

\section{GEOLOGICAL SETTING}

The fold and thrust belt of the Himalayan orogen (Fig. 1) consists of the following major structural units from north to south: South Tibet Detachment (STD) hanging wall, Main Central Thrust (MCT) sheet, Ramgarh Thrust sheet, Lesser Himalayan Duplex (LHD), Main Boundary Thrust (MBT) sheet and Main frontal Thrust (MFT) sheet. The STD hanging wall consists of Proterozoic-Eocene marine fossiliferous rocks of the Tethyan Himalayan Sequence; the MCT carries Proterozoic-Ordovician metamorphites of the GHC; the Ramgarh Thrust (locally designated as North Kalijhora Thrust, (Mukul, 2000) carries the Proterozoic Lesser Himalayan metamorphic sequence (DeCelles et al, 1998; Mukul, 2000) over the Gondwanas and the MBT carries the Gondwanas over the Siwaliks (Yin, 2006 and references therein). The southernmost unit of Himalayan orogen, the foothills, comprising of Miocene-Quaternary sedimentary succession bounded by the MFT in the south (Hodges, 2000; Yin, 2006 and references therein) (Fig. 2).

A sedimentary pile of $\sim 6 \mathrm{~km}$ thickness of fluvial conglomerates, sandstones and mudrocks has developed in the Indo-Gangetic foreland basins since the Middle Miocene, as a result of the uplift and concomitant erosion of the Himalayan orogenic belt (e.g., Nakayama and Ulak, 1999). These sedimentary strata comprise the Siwalik Group (cf. 
"the sub-Himalayas"; in Nepal, it is termed the Churia Group; Nakayama and Ulak, 1999) which thus forms the foreland part of the Himalayan fold and thrust belt (Yin, 2006 and references therein).

The Siwalik rocks are divided into three broad biostratigraphically-defined Subgroups (Upper, Middle and Lower) (Medlicott, 1864) which are further subdivided (Pilgrim, 1913) mainly on the basis of mammalian faunal assemblage (e.g., Nanda, 2002). In the western part of the Siwalik sequence, in Pakistan, magnetostratigraphy and lithostratigraphic subdivisions have been successfully applied (Johnson et al. 1982; Opdyke et al. 1982) to augment the mammalian stratigraphy, and such methods have also been applied more recently in other areas (e.g, Nakayama and Ulak, 1999 and references therein); however, application and correlation between these schemes remains somewhat problematic (Nanda, 2002). In general terms, the Siwalik Group deposits can be subdivided into: (1) an upward-coarsening mudrock-sandstone succession (Lower Siwalik Subgroup), (2) the sandstone-dominated Middle Siwalik Subgroup and (3) conglomerates, sandstones and mudrocks of the Upper Siwalik Subgroup (Kumar et al. 2003). The Siwaliks are well studied in the western and in Nepal Himalaya of the Himalayan orogenic belt (e.g., Brozovic and Burbank, 2000; Thomas et al. 2002; Sharma et al. 2002; Kumar et al. 2004; Ulak, 2005). This study will examine soft sediment deformation features from the eastern part of the Siwaliks, in Darjiling district.

In the eastern Himalayan sector, the Upper Siwalik Subgroup is either not exposed or absent (Banerji and Banerji, 1982). The Lower Siwalik rocks, exposed in the Tista River section around Kalijhora in Darjiling District, are carried by the South Kalijhora Thrust 
(SKT) over the Middle Siwaliks (Fig. 3). Lower Siwalik rocks are tectonically deformed into a series of open antiforms and synforms (Basak and Mukul, 2000).

The Middle Siwalik rocks are exposed in the footwall of the SKT and continue up to the mountain front for an aerial distance of $\sim \mathrm{km}$. The Middle Siwalik Subgroup of the area of study consists of alternating sandstones, mudstones, heteroliths (fine sand-mud intercalations) and subordinate but thick units of conglomerates (Table 1). The sandstones are mainly medium to coarse grained and were deposited within a fluvial setting (Acharyya, 1973; Banerji and Banerji, 1982). The Middle Siwalik section is repeated by several imbricate thrusts forming a frontal schuppen zone (Acharyya, 1976; Mukul, 2000; Mukul et al, 2007).

The Middle Siwalik succession (Banerji and Banerji, 1982) in the Darjiling Himalaya representing almost all the sedimentary strata of the Middle Siwaliks comprises of cyclic repetitions of conglomerate - pebbly sandstone - medium-grained sandstone - finegrained sandstone - mudstone associations. A detail litholog of the Middle Siwalik Subgroup of the Tista section is presented in Fig. 4.

\section{SOFT SEDIMENT DEFORMATION STRUCTURES}

Various types of soft sediment deformation structures are preserved in different horizons within the Middle Siwalik Subgroup. Soft sediment deformation structures are especially well developed in the heterolithic domain in the sequence. The deformation structures preserved are convolute lamination, flame structures, various kinds of deformed cross-stratifications and syn-sedimentary faults. 


\section{Convolute Lamination}

Convolute lamination are present in the sand-mud intercalated horizons or heteroliths (Fig. 5 and 6). This is a deformation feature typical of sediments in the soft state. The convolute laminations morphologically are simple to complex; often looks like broad hinge folds with variable geometry. Upward closing 'fold hinge' ('domes') of the folds remain unbroken and nowhere have we observed truncated heads of the domes. The layers containing the convolute lamination structures are sandwiched between undeformed layers having plane laminated or cross-stratified sedimentary strucutres.

\section{Flame Structure}

These are present within heterolithic units comprising of very thin sand-mud interlaminations (Fig. 6). These deformed horizons are overlain and underlain by mudrock layers without any load cast. Associated deformation features within the same horizons in the vicinity of the flames are convolute lamination. At a particular exposure the deformed horizon contains recumbent folded cross-strata adjacent to flame structure. Directions of the flames are upward, i.e. almost perpendicular to the palaeocurrent direction. The frontal part of the flame structure associated with convolute lamination show near orthogonal relation with the deformed lamination (Fig. 6).

\section{Deformed Cross-Stratification}

Deformed cross stratification within heterolith horizons are sandwiched between undeformed layers consisting of thin interlaminated fine sand and mud. Deformed crossstratification are either overturned or over-steepened. Overturned cross-strata form 
recumbent folds in the strike parallel section of the host bed (Fig. 7). Overturning direction and foreset inclination are concordant. In oversteepened cross strata (Fig. 8) the middle parts of the sets are inclined more steeply than the lower and the upper part. The deformed beds having recumbent folds and convolute laminations are present in succession of 3 or more units and they are bounded by undeformed strata.

Locally, small lensoidal fragments of cross-stratified units having a clearly different orientation to the surrounding cross-stratified sequence are preserved (Fig. 9).

\section{Syn-Sedimentary Fault}

Syn-sedimentary faults are occasionally observed within plane laminated sandstone beds where fault planes abut against overlying undeformed laminated sandstone of the same facies (Fig. 10). The hanging wall of the fault carries sandstone with curved lamina which are parallel to the fault plane.

\section{INTERPRETATION}

\section{Convolute Lamination}

Both fluvial processes and earthquakes can cause liquefaction of sediment, leading to the formation of convolute lamination and different water escape structures (Allen, 1977; Chakraborty, 1977). When deformation is controlled by fluvial processes, the tops of the domes of convolute lamina are likely to be broken, due to the unidirectional fluvial flow (Selley et al. 1963). According to Reineck and Singh (1980) convolute bedding associated with erosional surfaces may form due to current drag in fluvial environments. In the Middle Siwalik beds, the domes are intact and are not associated with erosional 
surfaces. These structures are restricted only to certain horizons, suggesting that momentary triggering episodes were responsible for development of these structures. Hence the deformation can be inferred to be syn-depositional and most likely resulted from seismic shock (cf. Friend et al. 1976; Cojan and Thiry, 1992; Davies et al. 2004). Smooth folds indicate liquefied state of the sediment during the folding. Convolute lamination with smooth troughs and domes are commonly developed by single or repeated triggers and the complex fold geometry may be due to repeated deformation (cf. Schneiderhan et al. 2005) that can only be attributed to recurrence of earthquake tremors.

\section{Flame Structure}

Formation of flame structure is attributed to directional fluidization and escape of water due to density contrast between sand and mud layers along the interface (e.g., Collinson and Thompson, 1982). Flame structures formed by fludization resulting from the load of overlying sediments are associated with load structures, however, in the Middle Siwalik sequence of the present area load casts are conspicuously absent in the horizon that contains flame structure. Therefore the development of the flames can be ascribed to earthquake induced (Visher and Cunningham, 1981; Obermeier, 1996) fluidization and resulting water escape, rather than to an autocyclic sedimentary origin.

\section{Deformed Cross-Stratification}

Overturning of cross-strata is thought to have been produced by a deformation mechanism triggered by earthquake or by dragging of a sand-loaded flow over cross-beds (McKee et al. 1962; Døe and Dott, 1980; Owen, 1995; Mazumder and Altermann, 2007). 
Steepening of foresets cannot be used as an identifying signature of a particular deformation process. The horizons preserving deformed cross strata are sandwiched between underformed plane laminated sand-mud layers. Thus the deformation may be syn- or meta-depositional (cf. Owen, 1995). As a consequence, the possibility of quick deposition of sand in high energy regime above unconsolidated sediment producing a shear stress and deforming the sediment underneath, can be eliminated. Deformed crossstrata are not extensive and so cannot be confidently attributed to fluvial dragging and shearing (Owen, 1995). Overlying undeformed beds, and the lateral persistence of various deformation features all through the deformed horizons indicating earthquake trigger (Mazumder and Altermann, 2007; Kundu and Goswami, 2008). According to Sims (1973) earthquake shocks can generate recumbent folds in sediments underlying mud layers near the surface. In the Middle Siwaliks these recumbent folded sand-mud lamina are overlain and underlain by muddy and fine sandy layers and hence may be considered as seismites. The perpendicular relation between the axial trend of the synsedimentary folds and the palaeocurrent direction observed in the area also strengthens our claim that the deformation is seismogenic. Closure direction of recumbent folds and the flame structures are different, indicating earthquake shocks as the most likely cause of development of these structures (cf. Upadhyay, 2001). Lensoidal fragments of crossstratified unit within the cross stratified sequence, must have been derived from elsewhere and the transportation is possibly seismic.

\section{Syn-Sedimentary Fault}


The syn-sedimentary faults are localized features. The surface do not have any diastrophic structures like slickensides on them or crushing adjacent to them. Hence the faulting here can be interpreted as a syn-depositional or meta-depositional feature. The fault plane is inclined opposite to the palaeoslope. Load features are also absent above the deformed horizon. So this faulting is not due to slope-gravity controlled slumping of the undeformed sediment. Hence a seismic shaking can be envisaged for the development of such soft sediment deformation features (cf. Singh and Jain, 2001).

\section{DISCUSSION}

Sediments in the Neogene Middle Siwalik Subgroup in the Darjiling area of the subHimalayas were deposited in the foreland basin of the Himalayan orogenic belt. The Neogene Middle Siwalik Group is a fluvial succession in which several horizons, particularly the heterolith ones, preserve soft sediment deformation structures. The observed soft sediment deformation features in the study area are convolute lamina, deformed cross-strata, flame structures and syn-sedimentary faults.

It is always challenging to distinguish the soft sediment deformation structures genetically, as similar features may form by different deforming mechanisms (e.g., Sims, 1973; Røe and Hermansen, 2006; Gruszka and Van Loon, 2007, 2009). When the deformations are seismogenic, the host sediment should generally be well sorted, with fine sand-mud interlayering, porous and wet (Dugué, 1995). Fluidization and liquefaction of sediment, which are the main mechanisms for such deformation structures (cf. Allen and Banks, 1972), can be triggered either by the sedimentation process itself (including the action of gravity on active bedforms; Jones and Rust 1983) or by earthquake shock (e.g., McKee et al. 1962; Rust, 1968; Seilacher, 1969; Turner, 1981; Allen, 1985; Røe, 
1987; Ord et al. 1988; Seth et al, 1990; Røe and Hermansen, 1993; Wells et al. 1993; cf. Bhattacharya and Bhattacharya, 2005 and references therein).

Non-tectonic or sedimentary soft sediment deformations are attributed to factors such as quick deposition, differential loading, slope controlled density currents, etc. (Bowman et al. 2004). Tectonic deformations or earthquake tremor-induced deformations result when seismic wave acceleration supercedes the shear strength of the sediment (Einsele et al. 1996) and when the sediment is subsequently liquefied and fluidized seismically (Obermeier, 1996). Liquefaction happens when upward fluid movement results from downward movement of grains; in contrast, fluidization of sediment happens when there is upward movement of fluid without any downward movement of grains (Lowe, 1975; Middleton and Southard, 1978).

When earthquake-induced deformation structures are preserved in a bed over long distances, they are commonly referred to as "seismites" (Seilacher, 1984) or "seismically triggered soft sediment deformation" structures (Ricci Lucchi, 1995). In the study area, only river and road sections can be investigated and thus the lateral continuity of the soft sediment deformation structures cannot be checked for long distances, although they are laterally persistent in the exposed portions. The types of deformation structures in different deformed horizons are dissimilar. If normal fluvial depositional processes were responsible, then it is more likely that the deformation structures would be similar. Soft sediment deformations are sandwiched between undeformed layers, suggesting that the deformations are syn- or rarely, meta-depositional. The presence of features such as synsedimentary fault, drifted lensoidal cross-stratified fragments with unmatched palaeoflow direction, overturned cross-stratification and flames with varying vergence are clearly 
indications of palaeoseismic origin of the structures (Singh and Jain, 2001; cf. Upadhyay, 2001).

Most of these structures can be ascribed to the effects of liquefaction and fluidization of unconsolidated sediment. Presence of various soft sediment deformation structures in a single bed or within a set of adjacent lamina sandwiched between undeformed beds points to momentary and synchronous origin of these structures. Soft sediment deformation structures of similar dimensions have been established as seismites from western part of the sub-Himalayas (Kumar et al. 2005; Singh et al. 2007). These structures pass the tests for sudden formation, synchroneity, size, tectonic and depositional setting as proposed by Wheeler (2002). Any zoned map distribution for such structures in the Siwaliks is unavailable and thus the related test is not performed. So earthquakes are the most plausible events responsible for the formation of these structures. A number of horizons in the outcropping sections are deformed which points to recurrence of the inferred earthquakes at intervals.

Naturally, we cannot fully exclude an autocyclic fluvial sedimentary origin for the observed soft sediment deformation features, but in each case, we have been able to at least argue, on the basis of field evidence, for a preferential seismic origin. The Siwalik sedimentation was taking place during and after the uplift and exposure of the GHC, which served as the source of Siwalik sediments (DeCelles et al. 1998; White et al. 2001) between 12 - 1 Ma (Sangode et al. 1996; Meigs et al. 1995). The approximate time of the deposition of Middle Siwalik is $\sim 11-7 \mathrm{Ma}$ (Yin, 2006 and references within). Thus seismic activities during deposition are a very logical explanation for the features we have discussed in this paper. The tectonic disturbances in the Siwalik sediments during its 
depositional stage have been induced from the movement of the Lesser Himalayan thrusts (Huyghe et al. 2001), formation of north-trending rifts in the eastern Himalaya (Harrison et al. 1995) and may also be from the STD along the Tibet-Bhutan border (Edwards and Harrison, 1997).

Many authors have worked on the relation between soft sediment deformation structures and earthquake intensity (Tasgin and Turkmen, 2009 and references within). According to Marco and Agnon (1995) liquefaction of unconsolidated sediment initiates over a magnitude 4.5 whereas according to Sims (1975) a magnitude of 6 or higher is necessary to deform an unconsolidated sediment horizon. However, other workers estimated that a magnitude of 2-3 is sufficient for soft sediment deformation (Seed and Idriss, 1971). According to Castilla and Audemard (2007) an earthquake of magnitude $\geq$ 7 is essential for thrusting and liquefaction takes place within magnitudes $5.5-7$ within $150 \mathrm{~km}$ of the epicentre for such a range of magnitude. Faulting in the Himalaya are well within the required distance of $150 \mathrm{~km}$ from the Siwaliks. Therefore the seismic tremors along the faults are the likely causes of the soft sediment deformation in the Middle Siwalik rocks.

Acknowledgements: A. K. acknowledges University Grants Commission, India for the research grant PSW-22/06-07 (ERO). This paper is a partial outcome of this research project. A. K. also acknowledges Dr. Kumkum Ganguly for her support during preparation of the MS. P.G.E. acknowledges funding from the National Research Foundation, South Africa and the University of Pretoria. 


\section{References:}

ACHARYYA, S.K. (1973) Late Palaeozoic glaciation vs. volcanic activity along the Himalayan Chain with special reference to the Eastern Himalayas. Him. Geol., v.3, pp.209-230.

ACHARYYA, S.K. (1976) On the nature of the Main Boundary Fault in the Darjiling subHimalaya. Geol. Surv. India Misc. Publ., v.24, pp.395-408.

ALLEN, J.R.L. (1977) The possible mechanics of convolute lamination in graded beds. Jour. Geol. Soc. (London), v.134, pp.19-31.

AlLEN, J.R.L. (1982) Sedimentary Structures-Their Character and Physical Basis, v2, Elsevier, Amsterdam, 663 pp.

ALLEN, J.R.L. (1985) Principles of Physical Sedimentology, Allen \& Unwin, London, $272 \mathrm{pp}$.

ALLEN, J.R.L. and BANKS, N.L. (1972) An interpretation and analysis of recumbent folded deformed cross-bedding. Sedimentology, v.19, pp.257-283.

BANERJI, I. and BANERJI, S. (1982) A coalescing alluvial fan model of the Siwalik sedimentation - a case study in the eastern Himalaya. Geol. Surv. India Misc. Publ., v.41, pp.1 - 12.

BASAK, K. and Mukul, M. (2000) Deformation mechanisms in the South Kalijhora Thrust and thrust sheet in the Darjiling Himalayan fold-and-thrust belt, West Bengal, India. Indian Jour. Geol., v.72(2), pp.143-152.

Bhattacharya, H.N. and BhatTacharya, B. (2005) Storm Event Beds in a Paleoproterozoic Rift Basin, Aravalli Supergroup, Rajasthan, India. Gond. Res. v.8(2), pp.231-239. 
Bowman, D., KorJenkov, A. and Porat, N. (2004) Late-Pleistocene seismites from Lake Issyk-Kul, the Tienshan range, Kyrghyzstan Sedim. Geol., v.163, pp.211-228. Brozovic, N. and Burbank, D.W. (2000) Dynamic fluvial systems and gravel progradation in the Himalayan foreland. Geol. Soc. Amer. Bull., v.112(3), pp.394412.

Castilla, R.A. and Audemard, F.A. (2007) Sand blows as a potential tool for magnitude estimation of pre-instrumental earthquakes. Jour. Seismol., DOI 10.1007/s10950-007-9065-z.

ChAKRABorty, A. (1977) Upward flow and convolute lamination. Senckenbergiana Marit, v.9, pp.285-305.

COJAN, I. and THIRY, M. (1992) Seismically induced deformation structures in Oligocene shallow marine and eolian coastal sands (Paris Basin). Tectonophysics, v.206, pp.7989.

Collinson, J.D. and Thompson, D.B. (1982) Sedimentary Structures, Allen \& Unwin, London, $194 \mathrm{pp}$.

DAVIES, N.S., TuRner, P. and SAnsom, I.J. (2004) Caledonide influences on the Old Red Sandstone fluvial systems of the Oslo region, Norway. Geol. Jour., v.40, pp.83 - 101 .

DeCelles, P.G., Gehrels, G.E., Quade, J., OJha, T.P., KapP, P.A. and Upreti, B.N. (1998) Neogene foreland basin deposits, erosional unroofing, and the kinematic history of the Himalayan fold and thrust belt, western Nepal. Geol. Soc. Amer. Bull., v.110, pp.2-21. 
DøE, T.W. and DotT, R.H.Jr. (1980) Genetic Significance of Deformed Cross Bedding With Examples from the Navajo and Weber Sandstones of Utah. Jour. Sedim. Petrol., v.50, pp.793-812.

DuguÉ, O. (1995) Seismite dans le Jurassique supérieur du Bassin anglo parison (Noemandie, Oxfordien supérieur, Calcaire gréseux de Hennequeville). Sedim. Geol. 99 pp. $73-93$.

EdWARDS, M.A. and HARrison, T.M. (1997) When did the roof collapse? Late Miocene north-south extension in the High Himalaya revealed by $\mathrm{Th}-\mathrm{Pb}$ monazite dating of the Khula Kangri granite. Geology, v.25, pp.543-546.

Einsele, G., Chough, S.K. and ShiKi, T. (1996) Depositional events and their records an introduction. Sedim. Geol. 104 pp.1-9.

Friend, P.F., Alexander-Marrack, P.D., Nicholson, J. and Yeats, A.K. (1976) Devonian sediments of the east Greenland II: Sedimentary Structures and Fossils. Meddeleser em Gronland, v.206(2), pp.1 - 91.

GruszKa, B. and VAN LoON, A. J. (2007) Pleistocene glaciolacustrine breccias of seismic origin in an active graben (central Poland). Sedim. Geol., v.193(1), pp.93104.

Harrison, T.M., CoPeland, P., Kidd, W.S.F..and Lovera, O.M. (1995) Activation of the Nyainqentanghla shear zone: implications for uplift of the southern Tibetan Plateau. Tectonics, v.14, pp.658- 676.

Harrison, T.M., Grove, M., Lovera, O.M., Catlos, E.J. And D’Andrea, J. (1999) The origin of Himalayan anatexis and inverted metamorphism: Models and constraints. Jour. Asian Earth Sci., v.17, pp.755-772. 
HodgES, K.V. (2000) Tectonics of the Himalaya and southern Tibet from two perspectives. Geol. Soc. Amer. Bull. v.112, pp.324-350.

Huyghe, P., Galy, A., Mugnier, J.L., France-Lanord, C. (2001) Propagation of the thrust system and erosion in the Lesser Himalaya: geochemical and sedimentological evidence. Geology, v.29, pp.1007- 1010.

Johnson, N.M., OpDYKe, N.D., JoHnson, G.D., LindSAY, E.H. and TAHIRKHELI, R.A.K. (1982) Magnetic polarity stratigraphy and ages of Siwalik group rocks of the potwar plateau, Pakistan. Palaeogeography Palaeoclimatology Palaeoecology, v.37, pp.17-42.

Jones, G. and Rust, B.R. (1983) Massive sandstone facies in the Hawkesbury Sandstone, a Triassic fluvial deposit near Sydney, Australia. Jour. Sedim. Petrol. V.53, pp.1249-1259.

KLEVERlaAn, K. (1987) Gordo Megabed. A possible seismite in a Tortonian submarine fan, Tabernas Basin, Province Almeria, Southeast Spain. Sedim. Geol., v.51, pp.165 180.

Kumar, R., Ghosh, S.K. and SANGode, S.J. (2003) Mio-Pliocene sedimentation history in the northwestern part of the Himalayan foreland basin, India. Curr. Sci., v.84(8), pp.1006-1113.

KumAR, R., GILL, G.S. and GuPTA, L.N. (2005) Earthquake induced structures in Pinjore Formation of Nadah area, Haryana. Jour. Geol. Soc. India., v.65, pp.346-352.

Kumar, R., SANGODE, S.J. and GHosh, S.K. (2004) A multistorey sandstone complex in the Himalayan foreland basin, NW Himalaya, India. Jour. Asian Earth Sci., v.23, pp.407-426. 
Kundu, A. and Goswami, B. (2008) A note on seismic evidences during during the sedimentation of Panchet Formation, Damodar Basin, Eastern India: Banspetali Nullah Revisited. Jour. Geol. Soc. India, v.72, pp.400-404.

LEEDER, M.R. (1987) Sediment deformation structures and the palaeotectonic analysis of sedimentary basins, with case-study from the Carboniferous of northern England. In: M.E. Jones and R.M.F. Preston (Eds.) Deformation of Sediments and Sedimentary Rocks. Geol. Soc. London Spec. Publ., 29 pp.137-146.

LowE, D.R. (1975) Water escape structures in coarse grained sediments. Sedimentology, v.22, pp.157-204.

Marco, S. and Agnon, A. (1995) Prehistoric earthquake deformations near Massada, Dead Sea Graben. Geology, v.23, pp.695-698.

Mazumder, R. and Altermann, W. (2007) Discussion on new aspects of deformed cross-strata in fluvial sandstones: Examples from Neoproterozoic formations in northern Norway by S.L. Røe and M. Hermansen. Sedim. Geol., v.198, pp.351-353.

Mazumder, R., VAn LoOn, A.J. and ARima, M. (2006) Soft-sediment deformation structures in Earth's oldest seismites. Sedim. Geol., v.186, pp.19-29.

McKeE, E.D., REYNoldS, M.A. and BAKER, C.H. (1962) Experiments on intraformational recumbent folds in cross-bedded sand. U.S.G. S. Professional Paper 450-D, pp.D155-D160.

MedLicotT, H.B. (1864) On the geological structure and relations of the southern portion of the Himalayan ranges between the rivers Ganges and the Ravee. Mem. Geol. Suvr. India, v.3(2), pp.1-212. 
Meigs, A.J., Burbank, D.W. and Beck, R.A. (1995) Middle-late Miocene (N10 Ma) formation of the Main Boundary Thrust in the western Himalaya. Geology, v.23, pp.423- 426.

Middleton, G.V. and Southard, J.B. (1978) Mechanics of sediment movement. Society of Economic Paleontologists and Mineralogists Short Course No. 3. Binghamton, New York.

Moores, E.M. and FAirbridge, R.W. (1997) Encyclopedia of European and Asian regional Geology. Springer, 804 pp.

Mukul, M. (2000) The geometry and kinematics of the Main Boundary Thrust and related neotectonics in the Darjiling Himalayan fold-and-thrust belt, West Bengal, India. Jour. Struc. Geol., v.22, pp.1261-1283.

Mukul, M., Jaiswal, M. and SinghVI, A.K. (2007) Timing of recent out-of-sequence active deformation in the frontal Himalayan wedge: Insights from the Darjiling subHimalaya, India. Geology, v.35(11), pp.999-1002.

NAGTEGaAl, P.J.C. (1963) Convolute lamination, metadepositional ruptures and slumping in an exposure near Pobla de Segur (Spain). Geologie en Mijnbouw, v.42, pp.363-374.

NagtegaAl, P.J.C. (1965) An approximation to the genetic classification of non-organic sedimentary structures. Geologie en Mijnbouw, v.44, pp.347-352.

NAKAYAma, K. and UlaK, P.D. (1999) Evolution of fluvial style in the Siwalik Group in the foothills of the Nepal Himalaya Sedim. Geol., v.125, pp.205-224.

NANDA, A.C. (2002) An introduction to the Mammalian fauna of the Siwalik system. Curr. Sci., v.83(6), p.771. 
NEGI, S.S. (1998) Discovering the Himalaya, Indus Publishing, New Delhi, 563p.

OBERMEIER, S.F. (1996) Use of liquefaction-induced features for paleoseismic analysis. Eng. Geol., v.44, pp.1-76.

Opdyke, N. D., Johnson, N.M., Johnson, G.D., LindsAY, E.H. and TAhIRKheli, R.A.K. (1982) Paleomagnetism of the middle siwalik formations of northern Pakistan and rotation of the salt range decollement, Palaeogeogaphy. Palaeoclimatology Palaeoecoogy, v.37, pp.1-15.

ORD, D.M., Clemmey H and Leeder M R (1988) Interaction between faulting and sedimentation during Dinatian extension of the Solway basin, SW Scotland. Jour. Geol. Soc. (London), v.145, pp.249-25.

OwEN, G. (1987) Deformation processes in unconsolidated sands. In: M.E. Jones and R.M.F. Preston (Eds.) Deformation of Sediments and Sedimentary Rocks. Geol. Soc. (London) Spec. Publ., Geol. Soc. London Spec. Publ. 29, pp.11- 24.

OWEN, G. (1995) Soft sediments deformation in Upper Proterozoic Torridonian Sandstones (Applecross Formation) at Torridon, Northwest Scotland. Jour. Sedim. Res. Section A, Sedimentary Petrology and Processes, v.65, pp.495-504.

PILGRIM, G.E. (1913) Correlation of the Siwalik with mammal horizon of Europe. Records Geol. Surv. India, v.43(4), pp.264-326.

Pope, M. C., ReAd, J.F., BAmbach, R. and Hofmann, H.J. (1997) Late Middle to Late Ordovician seismites of Kentucky, southeast Ohio and Virginia. Sedimentary recorders of earthquakes in Appalachian basin. Geol. Soc. Amer. Bull., v.109, pp.489 $-503$. 
REINECK, H.E. and SINGH, I.B. (1980) Depositional setimentary environments, SpringerVerlag, Berlin-Heideberg-New York, 439p.

RICCI LUCCHI, F. (1995) Sedimentographica. A photographic atlas of sedimentary structures ( $2^{\text {nd }}$ Edition), Columbia University Press, New York, 255p.

RøE, S.L. (1987) Cross-strata and bedforms of probable transitional dune to upper-stage plane-bed origin from a Late Precambrian fluvial sandstone, northern Norway. Sedimentology v.34(1), pp.89-101.

RøE, S.L. and Hermansen, M. (1993) Processes and products of large, Late Precambrian sandy rivers in Northern Norway. In: M. Marzo and C. Puigdefabregas (Eds.), Spec. Publ. Int. Assoc. Sedimentologists 17 pp.151-166.

RøE, S.L. and HeRMANSEN, M. (2006) New aspects of deformed cross-strata in fluvial sandstones: examples from Neoproterozoic formations in northern Norway. Sedim. Geol., v.186, pp.283-293.

RøE, S.L. and HERMANSEN M (2007) New aspects of deformed cross-strata in fluvial sandstones: Examples from Neoproterozoic formations in northern Norway- Reply. Sedim. Geol., v.198, pp.355-358.

RosetTI, D.F. and GóES A M (2000) Deciphering the sedimentological imprint of paleoseismic events and example from Aptian Codó Formation, northern Brazil. Sedim. Geol., v.135, pp.137 - 156.

RUST, B.R. (1968) Deformed cross-bedding in Tertiary-Cretaceous sandstone, Arctic Canada. Jour. Sedim. Res., v.38(1), pp.87-91. 
Sangode, S.J., KumAR, R. and GHOSH, S.K. (1996) Magnetic polarity stratigraphy of the Siwalik sequence of Haripur area (H.P.), NW Himalaya. Jour. Geol. Soc. India, v.47, pp.683- 704 .

SCHNEIDERHAN, E.A., BHATTACHARYA, H.N., ZimMERMANN, U. and GUTZMER, J. (2005) Archean seismites of the Ventersdorp Supergroup, South Africa South African Jour. Geol., v.108, pp.343-348.

SEED, H.B. and Idriss, I.M. (1971) Simplified procedure for evaluating soil liquefaction potential. Jour. Soil Mech. Found. Div. Amer. Soc. Civ. Eng., v.97, pp.1249-1273.

SEILACHER, A. (1969) Fault-graded beds interpreted as seismites. Sedimentology, v.13, pp. $155-159$.

SEILACHER, A. (1984) Sedimentary structures tentatively attributed to seismic events. Marine Geol., v.55, pp.1 - 12 .

Selley, R.C., Shearman, D.J., Sutton, J. and Watson, J. (1963) Some underwater disturbances in the Torridonian of Skye and Raasay, Geol. Mag., v.100, pp.224-243.

Seth, A., Sarkar, S. and Bose, P.K. (1990) Syn-sedimentary seismic activity in an immature passive margin basin (Lower Member of the Katrol Formation, Upper Jurassic, Kutch, India). Sedim. Geol., v.68, pp.279-291.

Sharma, M., Sharma, S., Shukla, U.K. and Singh, I.B. (2002) Sandstone body achitechture and stratigraphic trends in the Middle Siwalik succession of the Jammu area, India. Jour. Asian Earth Sci., v.20, pp.817-828.

SIMS, J.D. (1973) Earthquake-induced structures in sediments of Van Norman Lake, San Fernando, California. Science, v.182, pp.161 - 163. 
SIMS, J.D. (1975) Determining earthquake recurrence intervals from deformational structures in young lacustrine sediments. Tectonophysics, v.29, pp.144 - 152 .

SingH, S. and JAIN, A.K. (2001) Palaeoseismicity: Geological evidence along the Kaurik Chago fault-zone and other related areas in Lahaul-Spiti and Ladakh Himalaya. In: O.P. Varma (Ed.), Research Highlights in Earth System Science. Department of Science and Technology, India, Splecial Volume, 2 pp.205 - 225.

Singh, J., Sharma, U. and Kumar, R. (2007) Soft sediment deformation in the Morni area, NW Sub-Himalaya. Curr. Sci., v.98(8), pp.1151-1155.

TABAtA, H. (2004) On the Himalayan uplift and Himalayan corridors. Extended Abstracts: $19^{\text {th }}$ Hiamalaya - Karakoram - Tibet workshop, Niseko, Japan, pp.256 257.

TASGin, C.K. and TURKMEN, I. (2009) Analysis of soft-sediment deformation structures in Neogene fluvio-lacustrine deposits of Çaybağı Formation, Eastern Turkey. Sedim. Geol., v.218, pp.16-30.

Thomas, J.V., Parkash, B. and Mohindra, R. (2002) Lithofacies and palaeosol analysis of the Middle and Upper Siwalik Goups (Plio-Pleistocene), Haripur-Kolar section, Himachal Pradesh, India. Sedim. Geol., v.150, pp.343-366.

TURNeR, B.R. (1981) Possible origin of low angle cross-strata and horizontal lamination in Beaufort Group sandstones of the southern Karoo Basin. Trans. Geol. Soc. South Africa, v.84, pp.193-197.

ULAK, P.D. (2005) Paleohydrological reconstruction of Siwlaik Group in Surai khola section of west Nepal Himalaya. Jour. Nepal Geol. Soc., v.31, pp.33-42. 
UpADHYAY, R. (2001) Seismically-induced soft-sediment deformational structures around Khalsar in the Shyok Valley, northern Ladakh and eastern Karakoram, India. Curr. Sci., v.81, pp.600 - 604.

VAN LOON, A.J. (2009) Soft-sediment deformation structures in siliclastic sediments: an overview. Geologos, v.15(1), pp.3-55.

VisheR, G.S. and CunNingham R D (1981) Convolute laminations - a theoretical analysis: example of a Pennsylvanian sandstone. Sedim. Geol., v.28, pp.175 - 188 .

Wells, N.A., Richards S S, Peng S, Keattch S E, Hudson J A and Copsey C J (1993) Fluvial processes and recumbently folded crossbeds in the Pennsylvanian Sharon Conglomerate in Summit County, Ohio, U. S. A. Sedim. Geol., v.85, pp.63 83.

WHEELER, R.L. (2002) Distinguishing seismic from nonseismic soft-sediment structures: Criteria from seismic-hazard analysis. In: F.R. Ettensohn, N. Rast and C.E. Brett (Eds.), Ancient Seismites. Geol. Soc. Amer. Spec. Paper, pp.359 1-11.

White, N.M., Parrish, R.R., Bickle, M.J., Najman, Y.M.R., Burbank, D. and MaIthani, A. (2001) Metamorphism and exhumation of the NW Himalaya constrained by $\mathrm{U}-\mathrm{Th}-\mathrm{Pb}$ analyses of detrital monazite grains from early foreland basin sediments. Jour. Geol. Soc.(London), v.158, pp.625-635.

YIN, A. (2006) Cenozoic tectonic evolution of the Himalayan orogen as constrained by along-strike variation of structural geometry, exhumation history, and foreland sedimentation. Earth Sci. Rev., v.76, pp.1-131. 
Table Caption:

Table 1: Rock types and sedimentary structures of Middle Siwalik Subgroup in the Darjling district 


\section{Figure Captions:}

Figure 1. (a) A generalized map of the Himalayan orogen (after Yin 2006). (b) Detail map of the Tista River Section with a part of the area of study (marked box).

Figure 2. A generalized cross section across Himalaya showing major thrusts and litho-tectonic units (after Harrison et al, 1999).

Figure 3. Part of Tista Section showing the SKT ( South Kalijhora Thrusts), MBT (Main Boundary Thrust), folds in Lower Siwalik and the imbricate zone (multiple thrusts) in Middle Siwalik. (after Mukul 2000).

Figure 4. Litholog of Middle Siwalik along the Tista River Section from South to North.

Figure 5. Convolute lamination showing complex highly irregular fold geometry in heterolith. Coin diameter $2.5 \mathrm{~cm}$.

Figure 6. Association of flame structure and convolute lamina within same horizon in heterolith. Note the orthogonal relation between the flame and the overlying lamina. Pen length $15 \mathrm{~cm}$.

Figure 7. Folded cross bedded structure in heterolith. Pen length $13 \mathrm{~cm}$.

Figure 8. Cross beds show variation of inclination from top to bottom in foreset unit. Pen length $13.5 \mathrm{~cm}$.

Figure 9. Drifted lensoidal fragment of cross-stratified unit. Cross-strata within the lensoid unit are different in orientation to surrounding ones. Pen length $13.5 \mathrm{~cm}$. 
Figure 10. A syn-sedimentary fault (marked arrowhead) in the Middle Siwalik sandstone. Note that the fault truncates the lamina in the lower unit but it abut against the overlying lamina. Pen length $15 \mathrm{~cm}$. 
Table 1. Rock types and sedimentary structures of Middle Siwalik Subgroup in the Darjling district

\begin{tabular}{|c|c|c|c|}
\hline Lithology & Character & Thickness & Sedimentary structure \\
\hline Conglomerate & $\begin{array}{l}\text { Dark grey, oligomictic, } \\
\text { clast to sandy-muddy } \\
\text { matrix supported. } \\
\text { Angular to subrounded } \\
\text { clasts, largest clast } 17 \mathrm{~cm}\end{array}$ & $\begin{array}{l}\text { Individual } \\
\text { beds less than } \\
1 \mathrm{~m} \text { to } 5 \mathrm{~m}\end{array}$ & $\begin{array}{l}\text { Tabular and shallow } \\
\text { trough cross } \\
\text { stratification }\end{array}$ \\
\hline Pebbly sandstone & $\begin{array}{l}\text { Light to dark grey and } \\
\text { yellow. Pebbles are of } \\
\text { various sizes, angular to } \\
\text { rounded }\end{array}$ & $\begin{array}{l}\text { Individual } \\
\text { beds } 1 \text { to } 3 \\
\text { mt. }\end{array}$ & $\begin{array}{l}\text { Crude cross } \\
\text { stratification }\end{array}$ \\
\hline $\begin{array}{l}\text { Coarse to } \\
\text { medium grained } \\
\text { sandstone }\end{array}$ & $\begin{array}{l}\text { Yellow to brownish } \\
\text { yellow }\end{array}$ & $\begin{array}{l}\text { Individual } \\
\text { beds } 30 \mathrm{~cm} \text { to } \\
6 \mathrm{mt}\end{array}$ & $\begin{array}{l}\text { Sheet geometry and } \\
\text { lensoidal channel } \\
\text { geometry. Channels } \\
\text { with tabular and trough } \\
\text { cross stratification. }\end{array}$ \\
\hline $\begin{array}{l}\text { Fine sandstone } \\
\text { Some horizons } \\
\text { are interstratified } \\
\text { with thin dark } \\
\text { mud lamina } \\
\text { (heterolith). }\end{array}$ & Buff or yellow coloured & $\begin{array}{l}\text { Individual } \\
\text { beds less than } \\
1.5 \mathrm{mt} \text { thick }\end{array}$ & $\begin{array}{l}\text { Small troughs and } \\
\text { tabular cross strata are } \\
\text { main structures. } \\
\text { Heteroliths preserve soft } \\
\text { sediment deformation } \\
\text { structures. }\end{array}$ \\
\hline
\end{tabular}


a

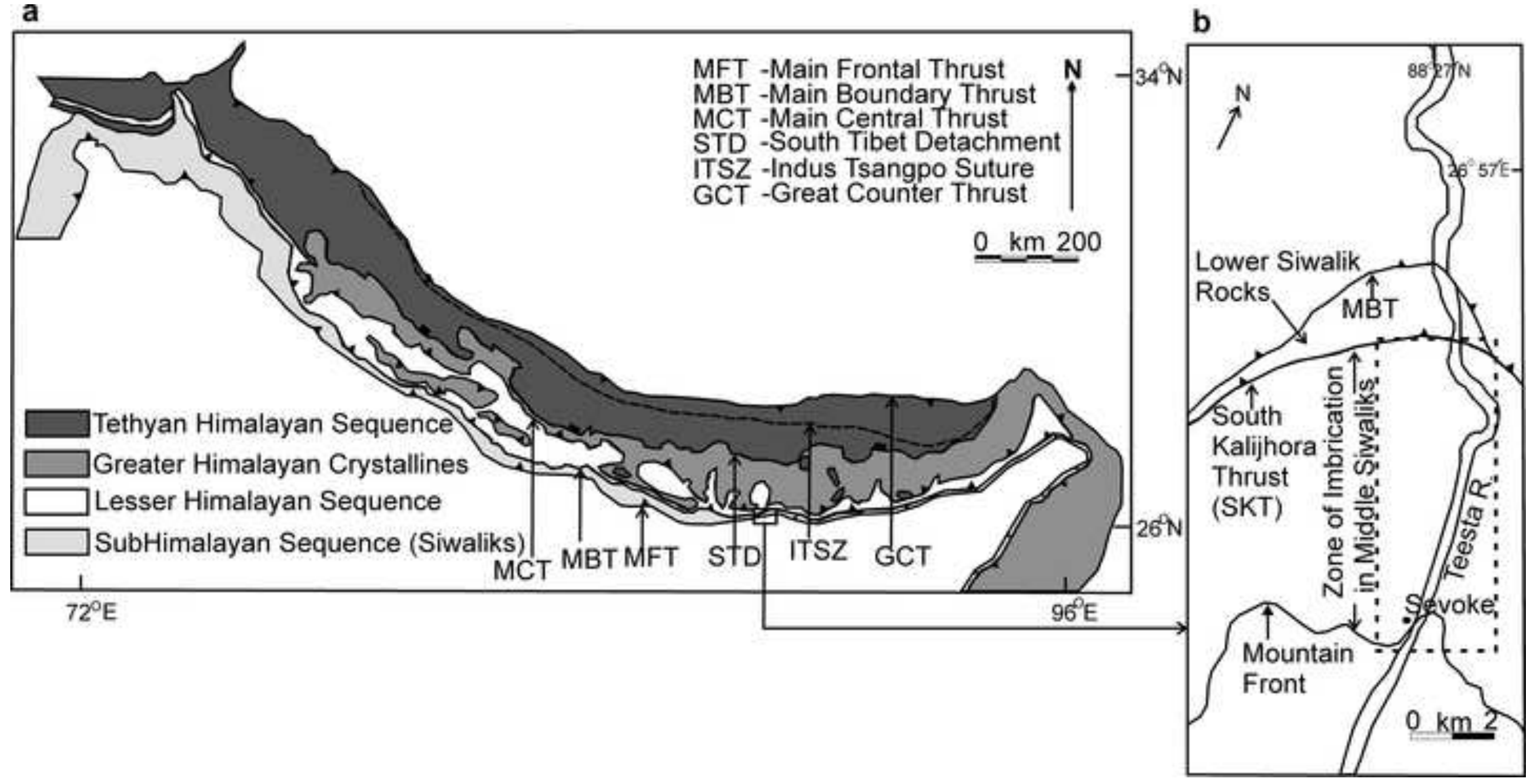




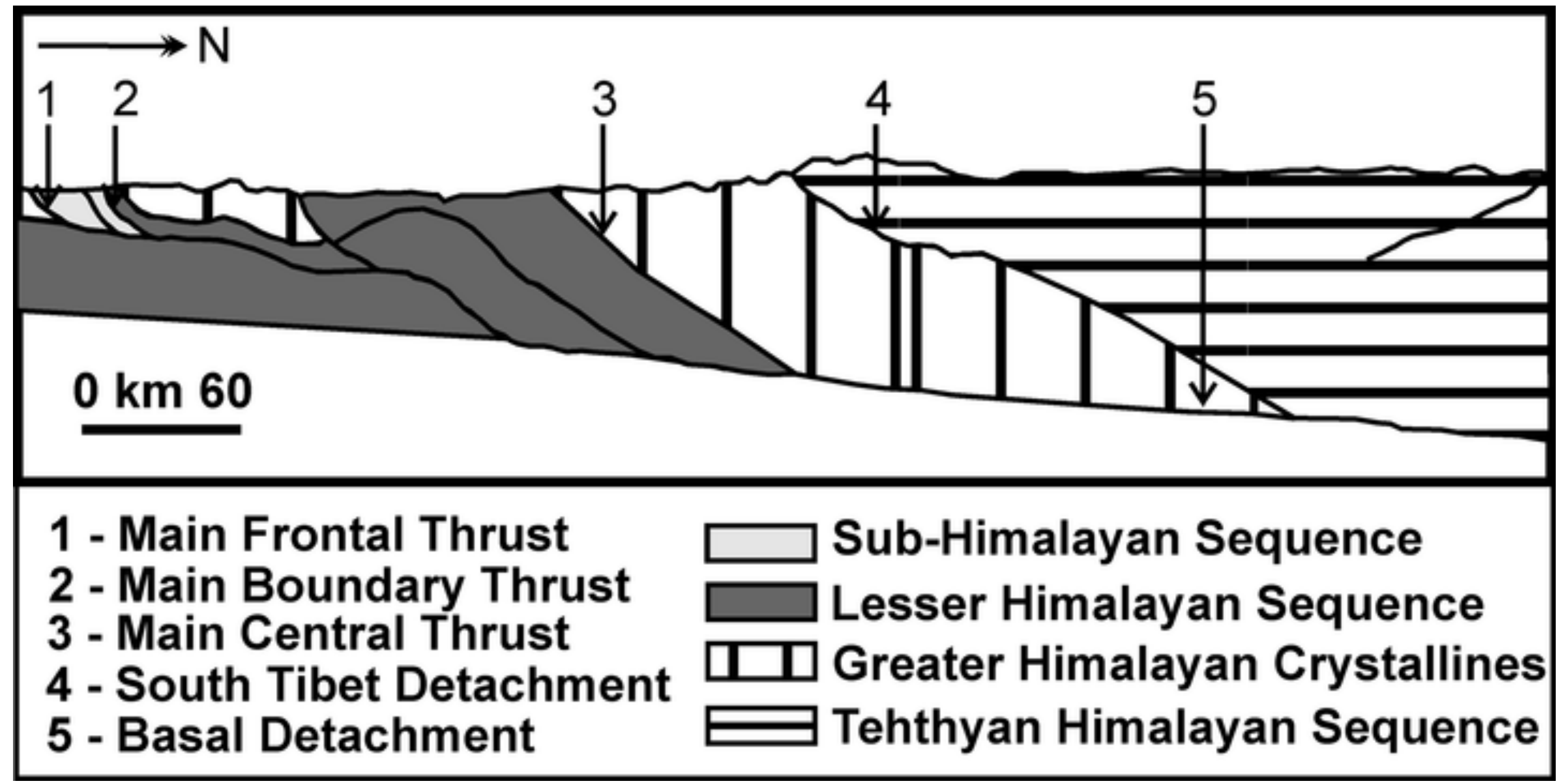




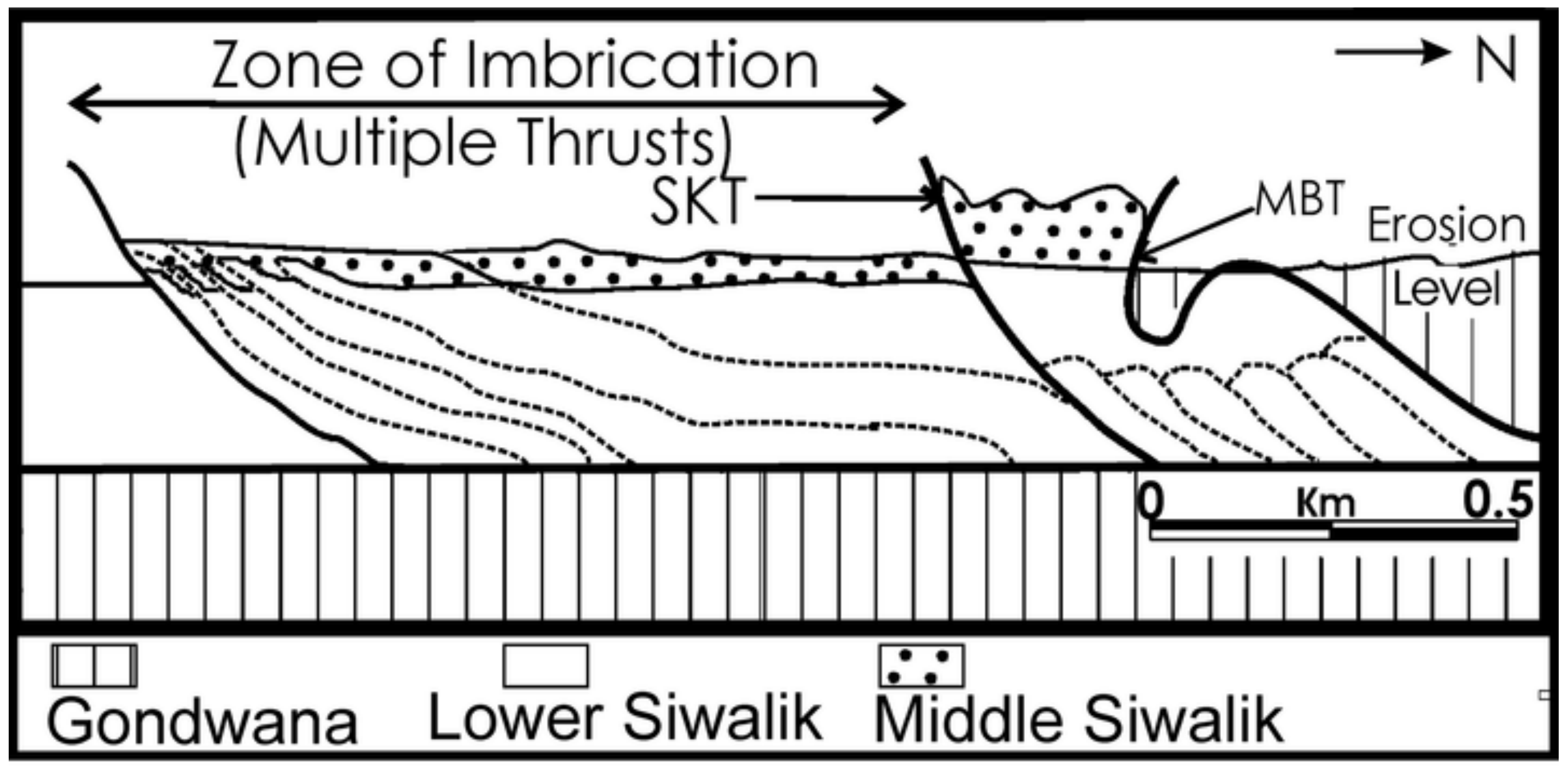




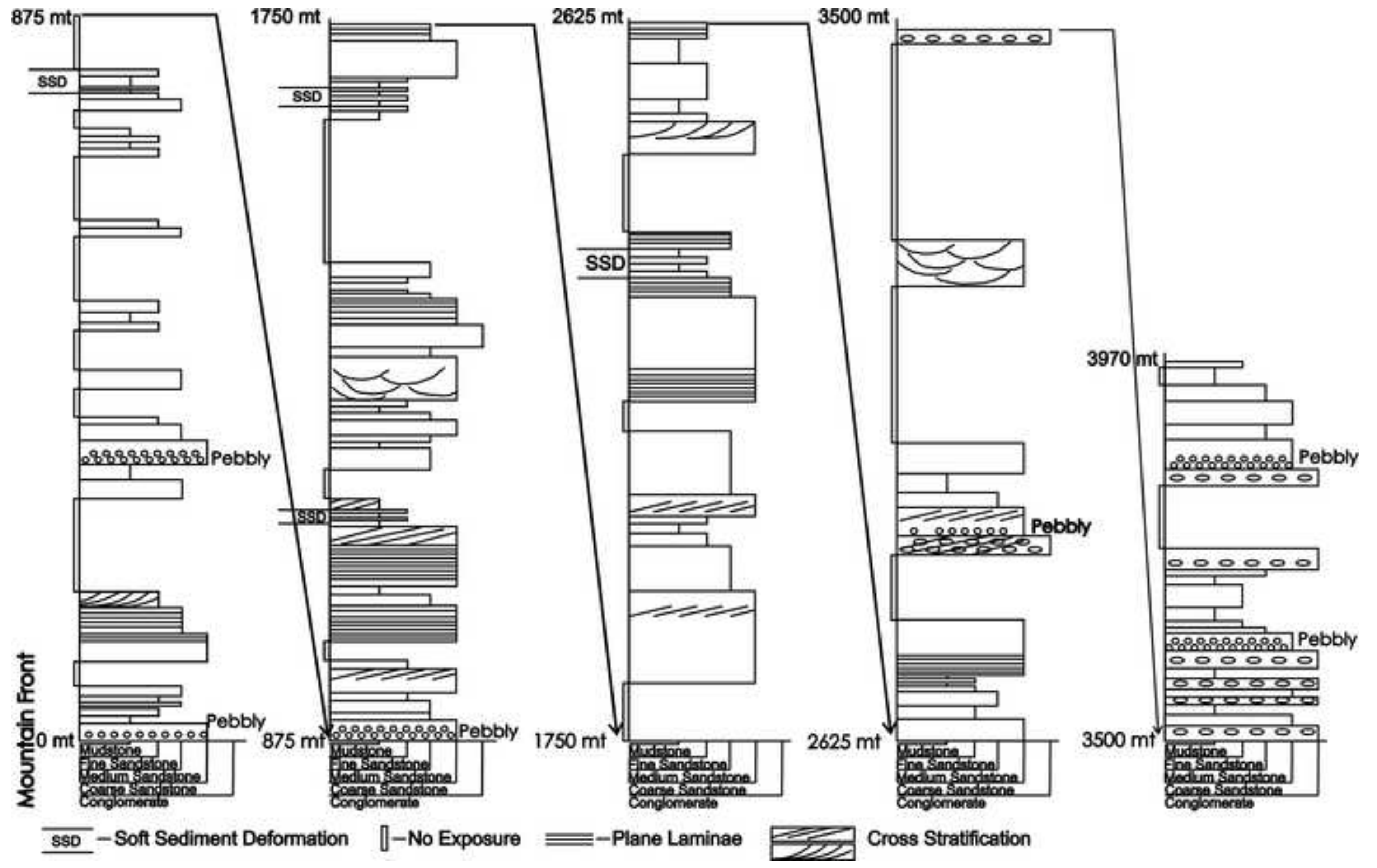




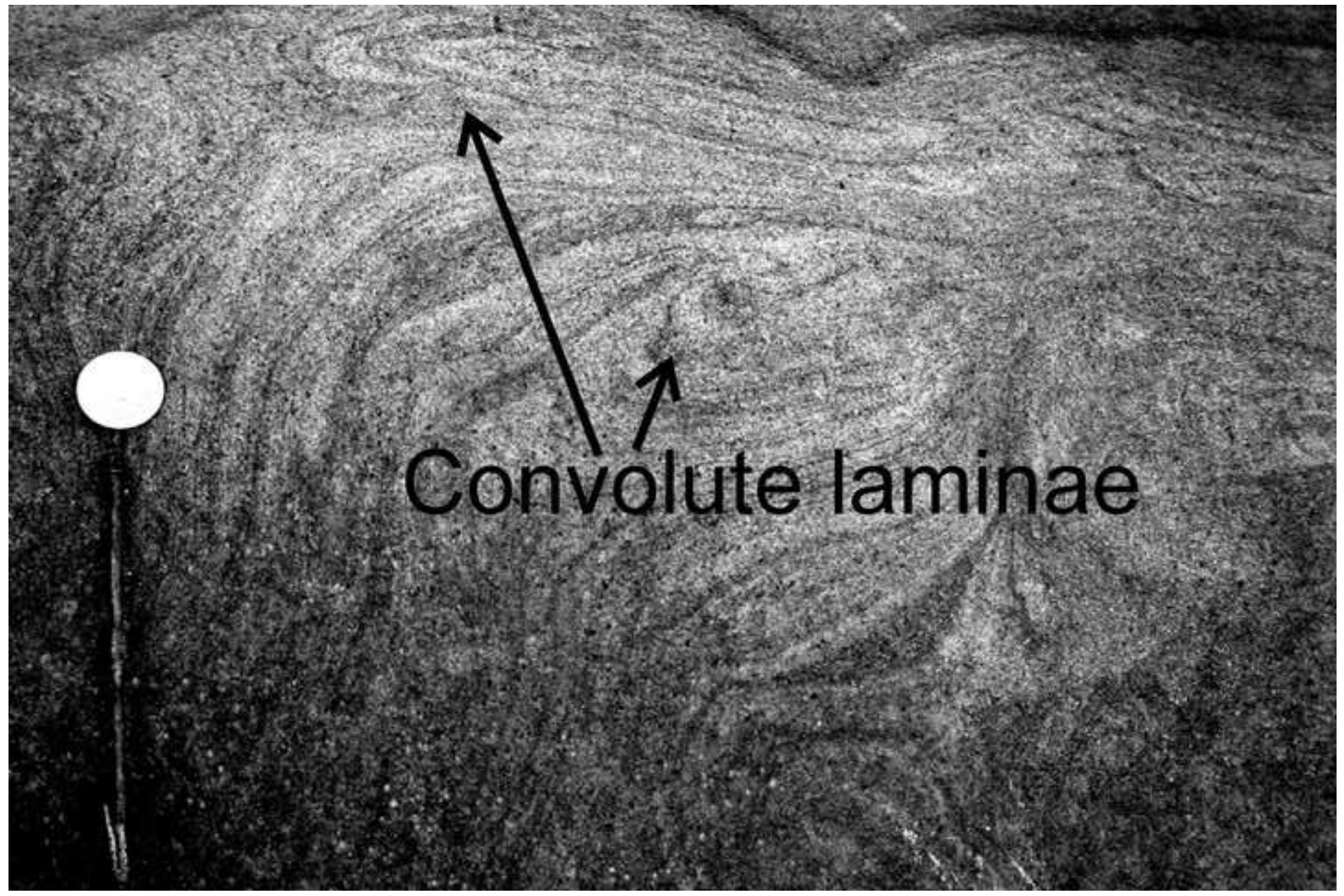




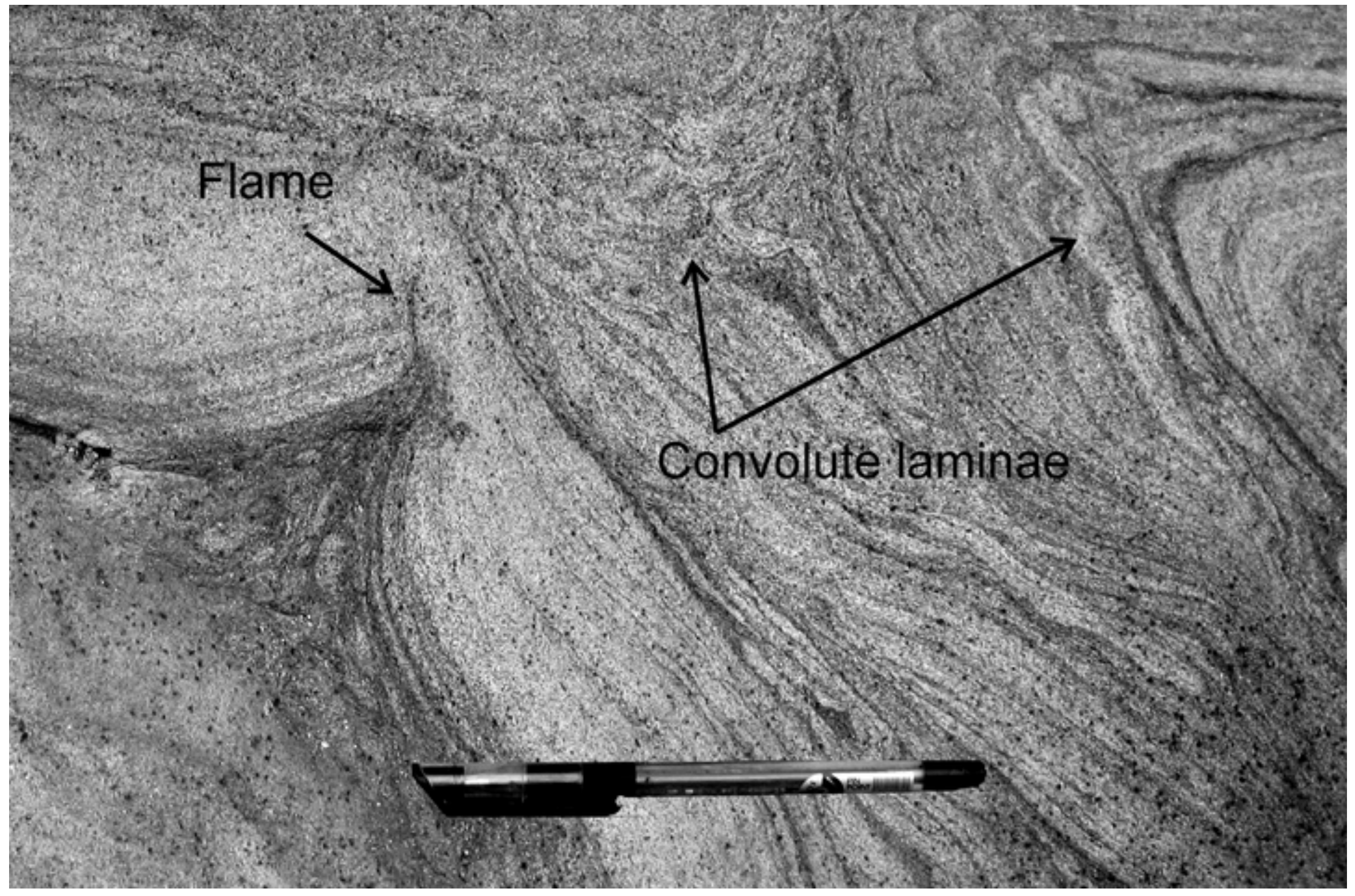




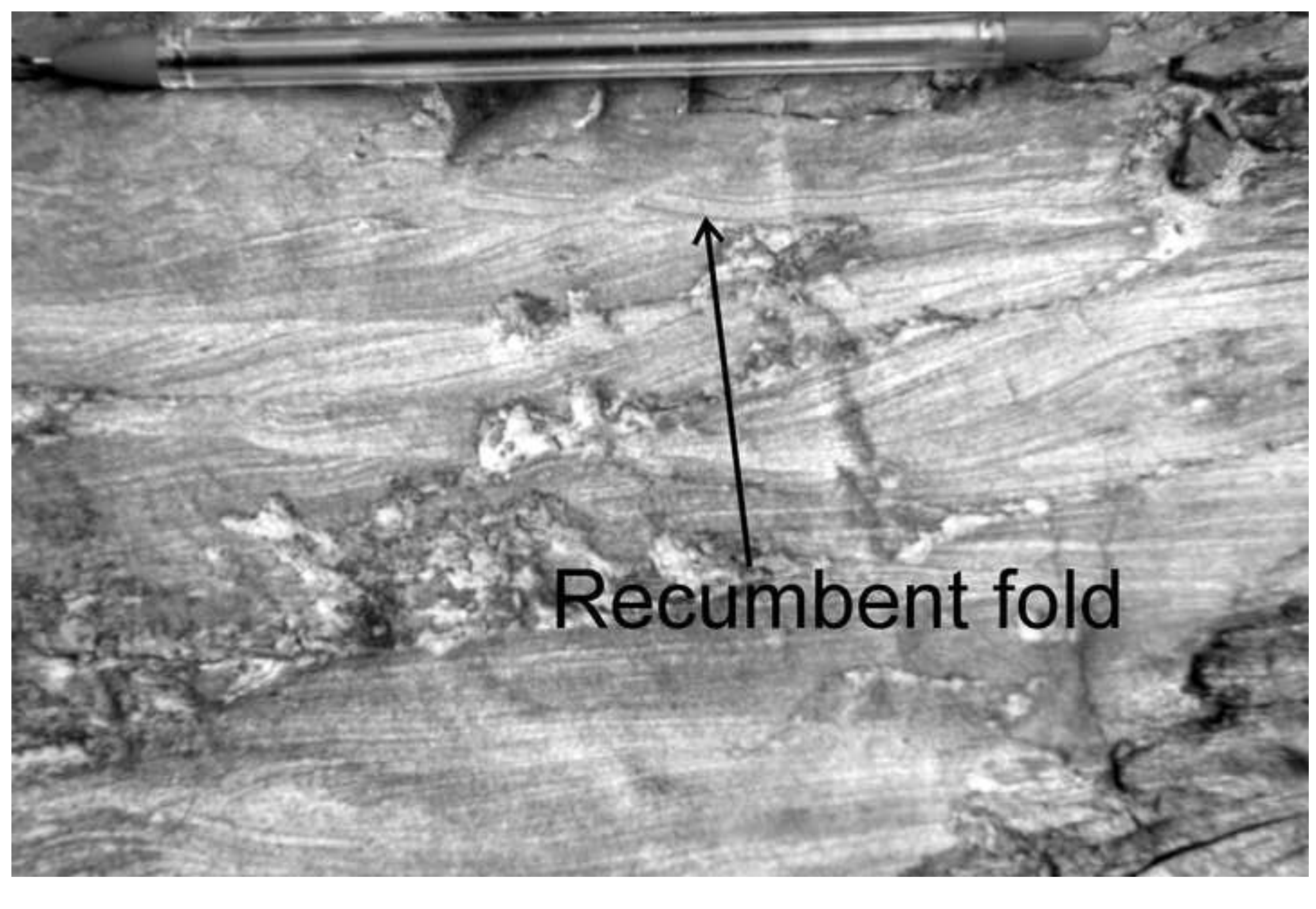

Figure
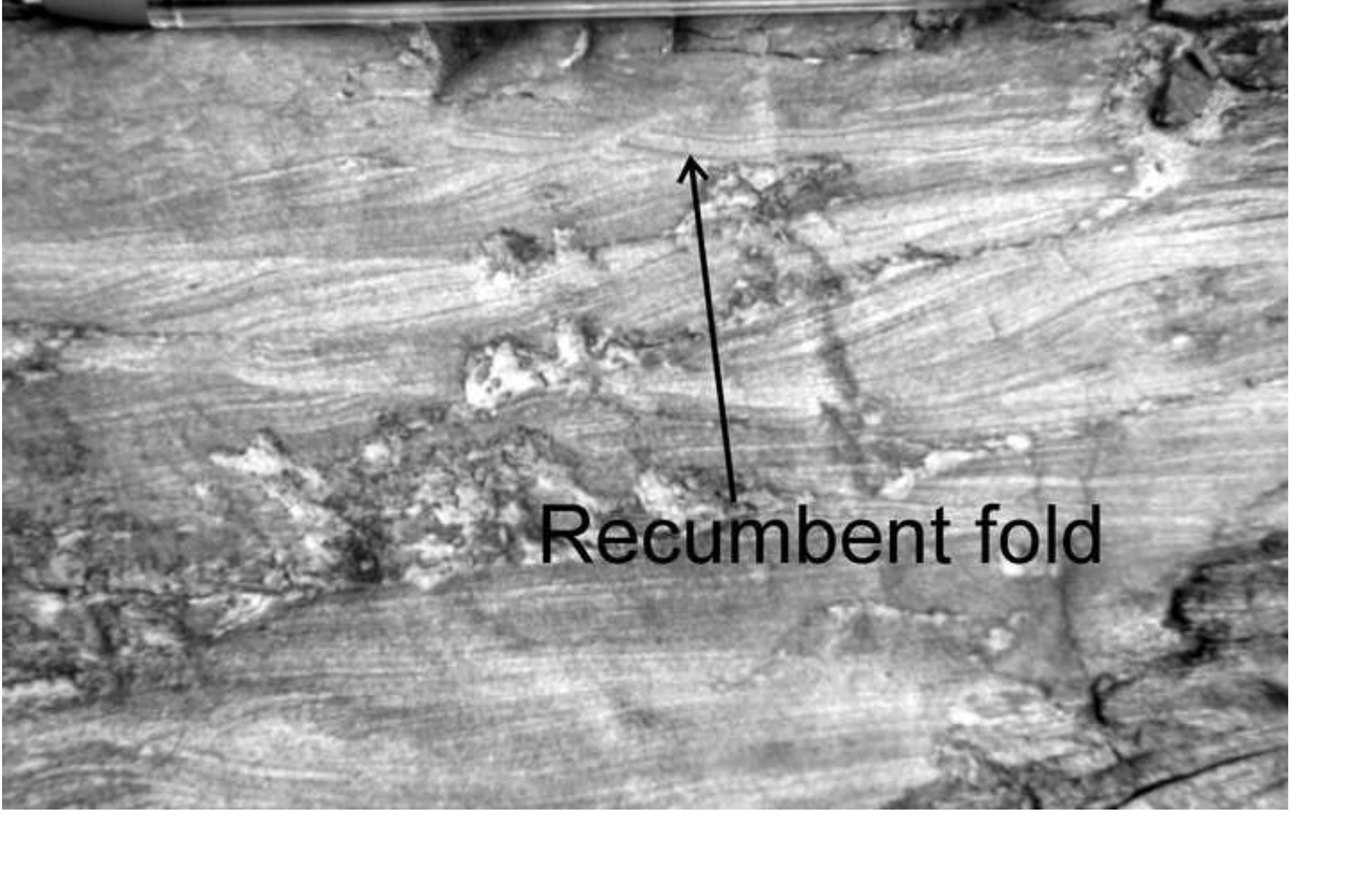

.
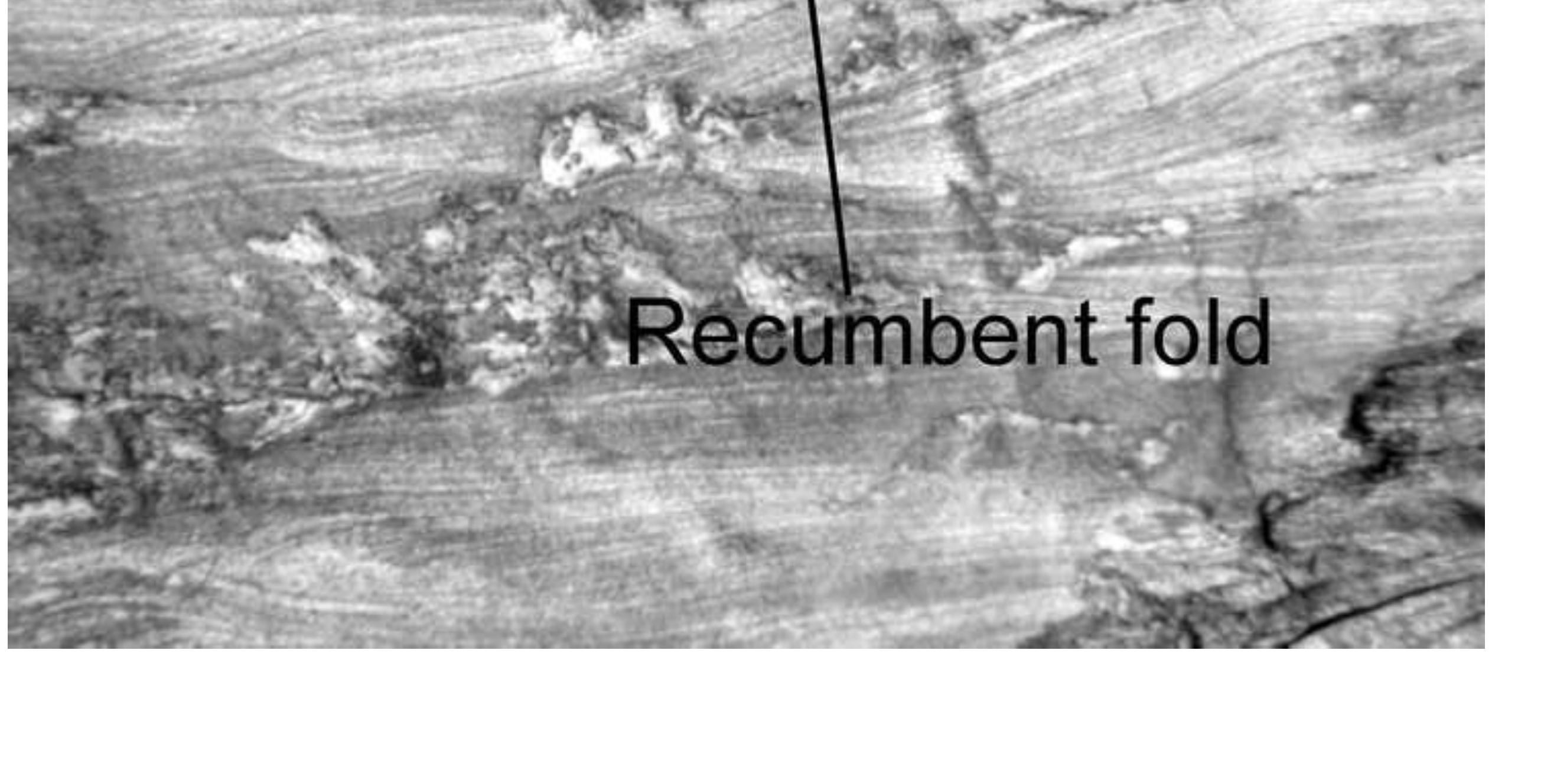


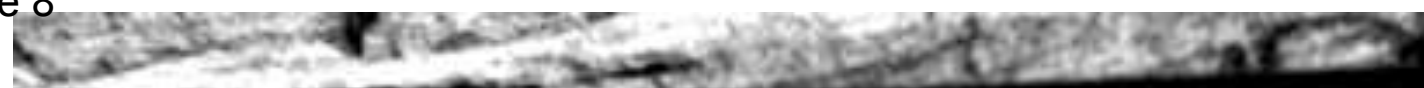

CV sonNea

Oversteepened part keteres of cross bed $\sqrt{ }$.

2. $20.0 \mathrm{~s}$.

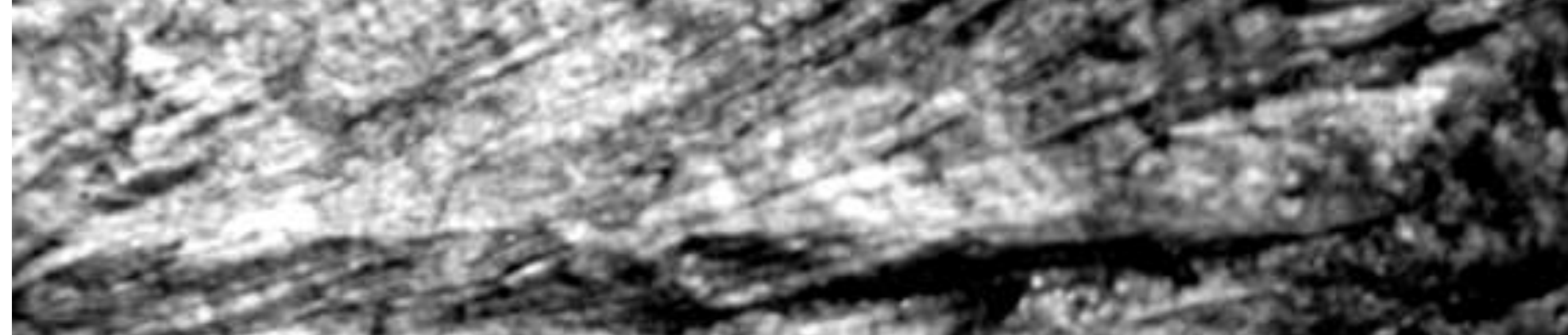

cor

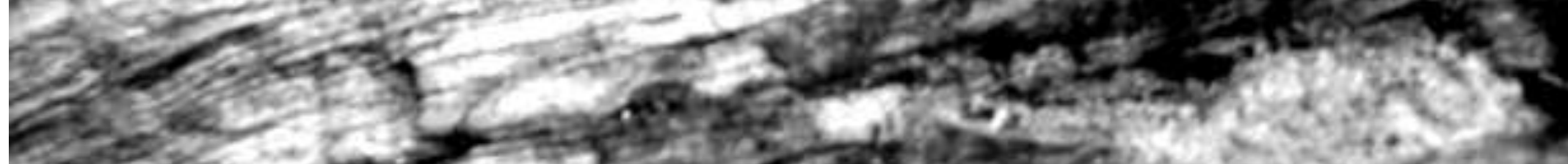

Q

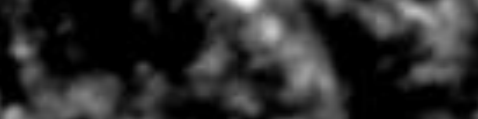

8

?

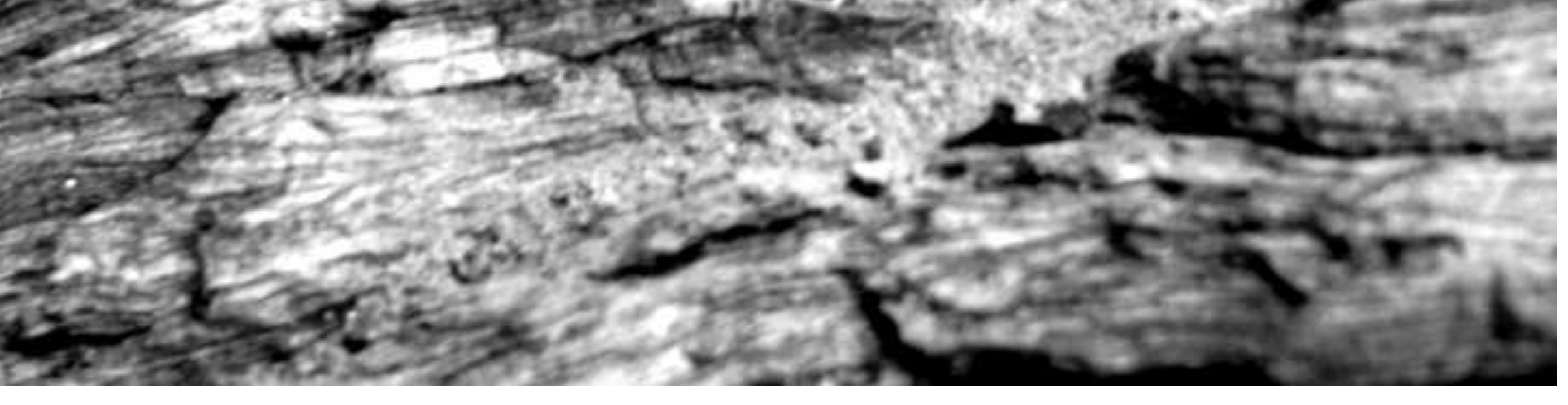




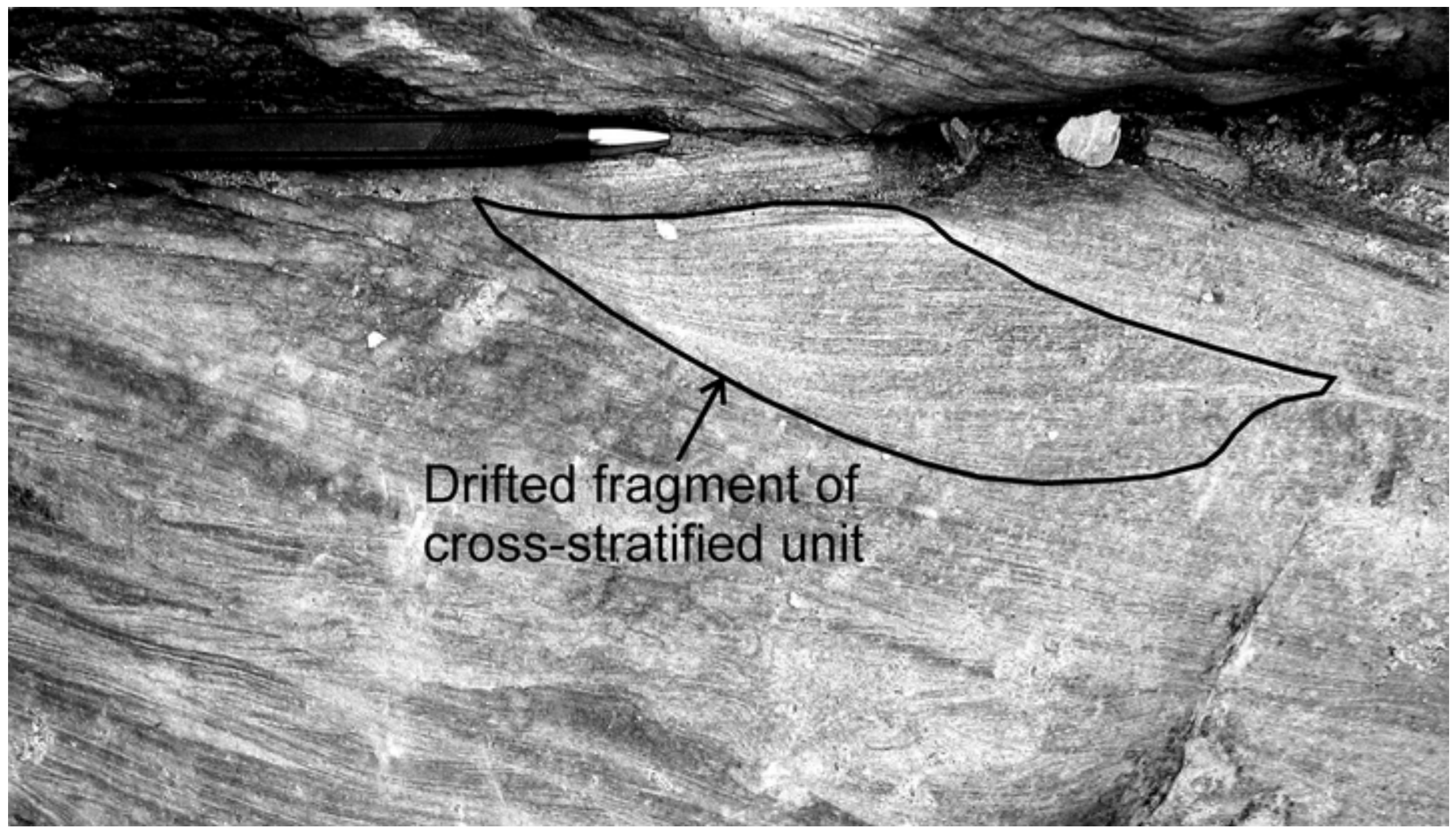




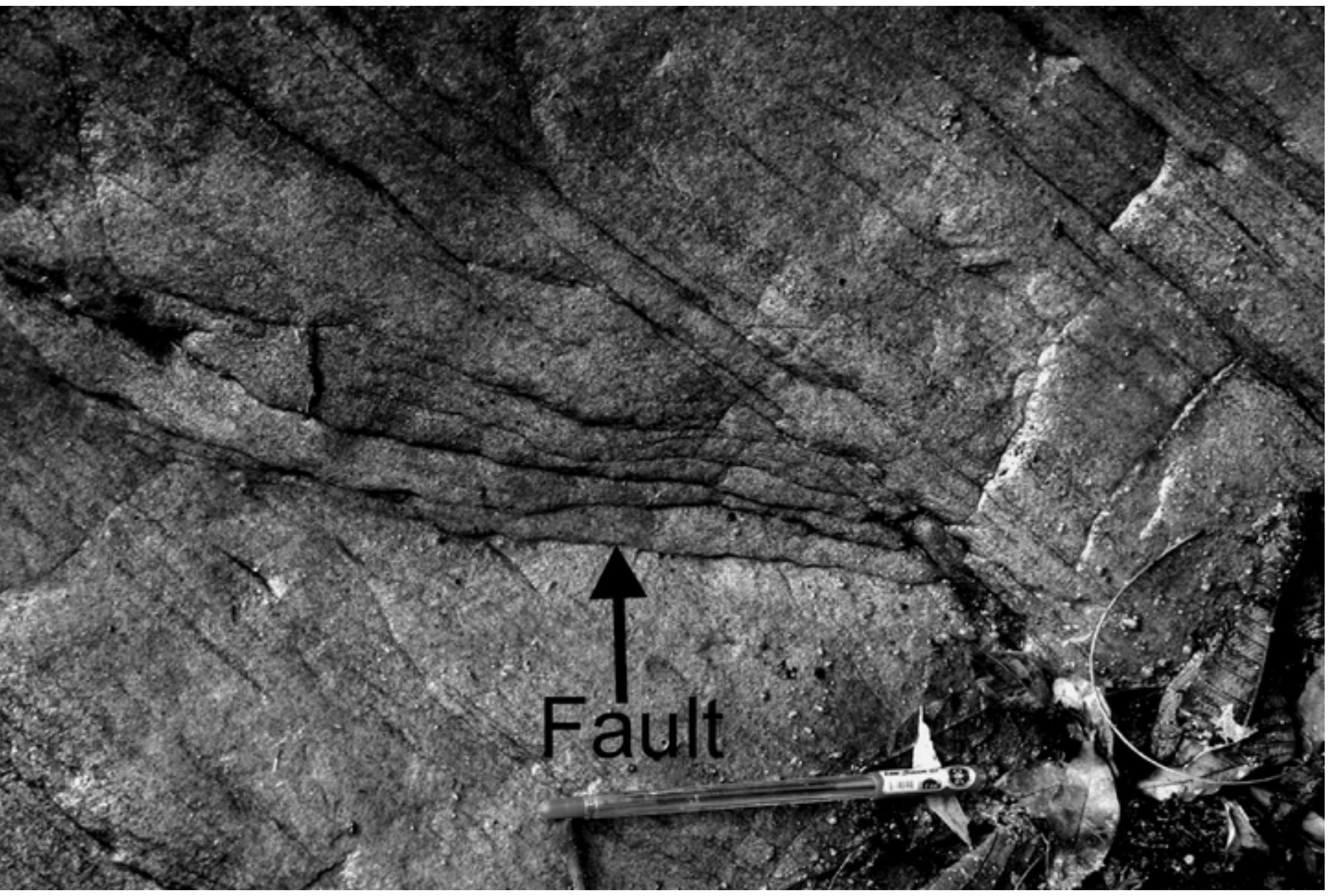

